\title{
Menuju Ke Arah Pengembangan Ilmu Falak
}

\author{
Ahmad Junaidi \\ STAIN Ponorogo ahjunaidi@gmail.com
}

\begin{abstract}
Abstrak
Pragmatisme, barangkali inilah racun yang sedang menjangkiti umat Islam. Tidak terkecuali para ilmuwannya, termasuk di dalamnya ilmuwan Falak. Apa yang sudah diletakkan dasar-dasarnya secara massif oleh salafus salih seakan hilang atau tidak mampu kita warisi. Sehingga Ilmu Falak hanya mengkaji waktu ibadah, yang itupun masih jauh dari kemaslahatan umat karena masih banyak menyisakan persoalan dalam penyatuan waktu ibadah umat Islam. Lebih parah lagi yang terjadi di Indonesia, sebuah metode bisa berubah menjadi aliran yang menjadi penciri dari organisasi kemasyarakatan. Sehingga gesekan antar ormaspun sulit dihindari akibat perbedaan tersebut. Maka sudah waktunya kita kembalikan Ilmu Falak pada khittah asalnya, sehingga terbebas dari reduksireduksi yang tidak menguntungkan bagi perkembangan ilmu pengetahuan. Pereduksian bidang kajian Ilmu Falak tidak membuat pemahaman terhadap ilmu ini semakin baik, tapi hanya mengarahkan kepada pragmatism berfikir dan mengkotak-kotak umat. Maka semangat integrasi keilmuan dan unity of science yang diusung UIN, kita jadikan pijakan untuk mengembalikan Ilmu Falak kepada konsep awal yang digagas para pendahulu. Untuk mencapai hal tersebut, ada 2 hal yang harus segera dipersiapkan, yakni kurikulum dan sarana teknologi untuk menopangnya.
\end{abstract}

\section{Kata Kunci: ilmu falak, kauniyah, integrasi}

\section{Pendahuluan}

Kalau kita bicara tentang Ilmu Falak atau yang dalam Bahasa Inggris disebut Astronomi, tentu sekarang ini yang menjadi rujukan paling utama adalah NASA (Naitonal Aeronautics and Space Adminstration), lembaga pemerintah milik Amerika Serikat yang bertanggung jawab atas program luar angkasa AS dan penelitian umum luar angkasa jangka panjang. Organisasi ini bertanggung jawab atas program penelitian luar angkasa bagi masyarakat sipil, aeronautika, dan program kedirgantaraan. NASA didirikan pada 29 juli 1958 oleh
Presiden Eisenhower. ${ }^{1} \quad$ Usia yang masih sangat muda bila kita menilik ke belakang tentang peranan umat Islam pada masa-masa keemasan dalam meletakkan dasar-dasar bagi kemajuan ilmu pengetahuan.

Lahirnya NASA bisa dikatakan sebagai salah satu bentuk dominasi kemajuan barat dalam Iptek, dan menjadi pukulan hebat terhadap umat Islam yang sudah meletakkan dasar-dasar pengetahuan sedemikian rupa pada masa lalu, namun tidak diwarisi oleh umat Islam itu sendiri malah diwarisi oleh barat yang notabene non-muslim.

\footnotetext{
${ }^{1}$ https://id.wikipedia.org/wiki/NASA (diakses 10 Januari 2016).
} 
Al-Qur'an yang ayat-ayatnya diturunkan sekitar 14 abad yang lalu mengandung uraian garis besar mengenai penciptaan alam semesta ini, namun umat yang awam tidak mengetahui maknanya secara jelas. Sebab rincian dari skenario kejadian itu terdapat dalam ayat kauniyah yang tidak mampu dibaca umat ini, karena fisika dan sains pada umumnya telah ditinggalkan sejak 6 abad yang lalu. Umat ini barangkali sudah sangat jarang sekali memiliki orang yang disebut dalam surat Ali Imran ayat 190-191 sebagai Ulu alAlbab. ${ }^{1}$

Saat ini ilmu falak atau astronomi di kalangan umat Islam hanya membahas hal-hal praktis yang terkait dengan penjadwalan waktu dan arah ibadah dengan menggunakan 2 macam benda langit sebagai parameternya (matahari dan bulan). Saat ini, yang dipahami sebagai Ilmu Falak adalah hanya berkutat pada masalah waktu salat,

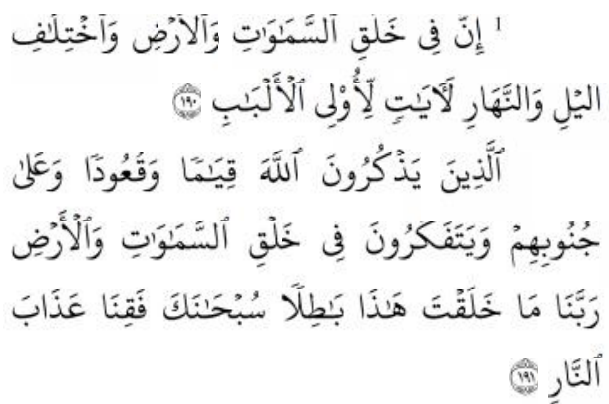

"Sesungguhnya dalam penciptaan langit dan bumi, dan silih bergantinya malam dan siang terdapat tanda-tanda bagi orangorang yang berakal,

191. (yaitu) orang-orang yang mengingat Allah sambil berdiri atau duduk atau dalam keadan berbaring dan mereka memikirkan tentang penciptaan langit dan bumi (seraya berkata): "Ya Tuhan Kami, Tiadalah Engkau menciptakan ini dengan sia-sia, Maha suci Engkau, Maka peliharalah Kami dari siksa neraka”. arah kiblat, awal bulan qamariyah dan gerhana. Ini hanyalah sebagian kecil dari wilayah kajian astronomi apalagi fisika dan sains pada umumnya, yang sudah diletakkan dasar-dasarnya oleh salaf al-salih. Padahal observasi di barat sudah mengarah pada pencarian planet lain yang mungkin untuk ditinggali serta peradaban lain di luar peradaban manusia di bumi.

Lebih ironis lagi pereduksian wilayah kajian ini bukan membuat kajiannya semakin baik, tetapi malah hanya membuat pemikiran umat Islam semakin terbelenggu dan terjebak pada fanatisme pemikiran masing-masing individu dan kelompok yang jauh dari kemaslahatan bersama. Saat ini umat ini hanya terjebak pada diskusi pemahaman dalil terkait dengan penggunaan hisab dan ru'yat, tanpa bisa berbuat banyak untuk bisa menghasilkan hal-hal yang lebih berarti bagi pengembangan ilmu ini. Lebih parah lagi yang terjadi di Indonesia, hisab dan ru'yat masingmasing seakan sudah menjadi penciri dari organisasi kemasyarakatan tertentu dalam pengambilan keputusan penanggalan yang dianggap sebagai metode yang absolute, bahkan sering kali tidak mengindahkan keputusan pemerintah sebagai uli al-amr.

Untuk itu perlu dilakukan usaha untuk merubah mindset umat Islam agar tidak terlalu lama hidup dalam kegelapan akibat ortodoksi keilmuan masing-masing kelompok dan melangkah untuk menerima estafet keilmuan yang sudah lepas dari genggaman umat Islam. 


\section{Pengertian Ilmu Falak}

Dalam bahasa Arab, kata alfalak itu semakna dengan kata almadar yang berarti garis/tempat perjalanan bintang. ${ }^{1}$ Sedang dalam bahasa Inggris, ia semakna dengan kata orbit yang berarti lingkaran. ${ }^{2}$ Jadi kalimat: Orbit of the earth about the sun berarti lingkaran bumi sekeliling matahari. Kadang-kadang, kata falak itu berarti "lingkaran langit atau cakrawala". ${ }^{3}$ Di dalam alQur'an, kata falak ini dapat kita temukan sebanyak dua kali, yakni dalam surat al-Anbiya' ayat 33 dan Yasin ayat 40, dan masing-masing diberi makna "garis edar". 4 Sementara dalam terjemahan bahasa Inggris, Yusuf Ali menggunakan makna "orbit". 5

Ilmu ini disebut Ilmu Falak, karena ilmu ini mempelajari lintasan benda-benda langit. Disebut juga dengan Ilmu Hisab, karena ilmu ini menggunakan perhitungan. Disebut pula dengan Ilmu Rashd, karena ilmu

1 A.W. Munawwir, Kamus AlMunawwir Arab-Indonesia (Surabaya: Pustaka Progressif, Edisi Kedua, Cet. XIV, 1997), 1072.

2 John M. Echols dan Hassan Shadily, Kamus Inggris Indonesia, (Jakarta: PT. Gramedia, 1983), 407.

3 Departemen Pendidikan dan Kebudayaan, Kamus Besar Bahasa Indonesia, (Jakarta: Balai Pustaka, Edisi Kedua, Cet. IX, 1999), 274.

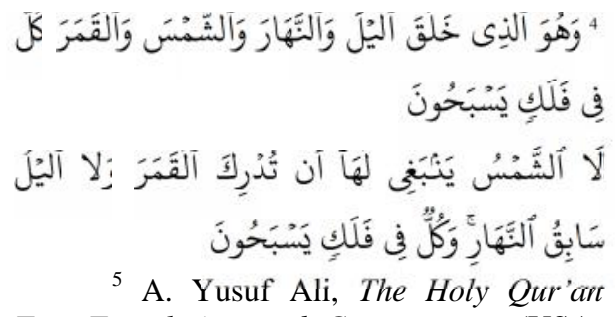

Text Translation and Commentary, (USA: Amana Corp, 1934), 1179. ini memerlukan pengamatan. Juga disebut dengan Ilmu Miqat, karena ilmu ini mempelajari batas-batas waktu. ${ }^{6}$

Adapun dalam pengertian istilah, banyak definisi yang dikemukakan para ahli, antara lain:

1. Ilmu Falak adalah ilmu pengetahuan yang mempelajari benda-benda langit, tentang fisiknya, geraknya, ukurannya dan segala sesuatu yang berhubungan dengannya. ${ }^{7}$

2. Ilmu Falak adalah ilmu yang mempelajari benda-benda langit, matahari, bulan, bintang dan planetplanetnya. $^{8}$

3. Ilmu Falak adalah ilmu pengetahuan mengenai keadaan (peredaran, perhitungan dsb.) bintangbintang. ${ }^{9}$

Dari berbagai definisi di atas, kiranya dapat disimpulkan bahwa pengetahuan tentang letak, pergerakan dan sifat-sifat matahari, bulan, bintang, planet(termasuk bumi) disebut ilmu Falak atau Astronomi. Ilmu Falak atau Astronomi mempelajari hal yang berkaitan dengan benda-benda langit, baik dari segi bentuk, ukuran, fisik, posisi, gerakan maupun hubungan satu dengan lainnya. Ilmu Falak juga

\footnotetext{
${ }^{6}$ Muhyiddin Khazin, Ilmu Falak dalam Teori dan Praktik (Yoyakarta: Buana Pustaka, 2004), 1.

Abdul 'Aziz Dahlan (ed.), Ensiklopedi Hukum Islam, (Jakarta: PT. Ichtiar Baru Van Hoeve, Cet. I, Jilid I, 1997), 304.

8 Hafidz Dasuki, Ensiklopedi Islam, (Jakarta: : PT. Ichtiar Baru Van Hoeve, Cet. I, Jilid I, 1994), 330.

9 Departemen, Kamus, 274.
} 
disebut Kosmografi. Bila ilmu Falak bermakna pengetahuan bidang edar, maka Kosmografi berarti catatan tentang alam semesta (kosmos = alam semesta; graphein $=$ menulis $){ }^{1}$

Dari berbagai devinisi tersebut, sebenarnya ilmu Falak atau Astronomi tidak hanya terbatas mempelajari matahari dan bulan sebagai penanda waktu tetapi seluruh alam semesta ini menjadi obyek kajian ilmu falak.

\section{Ruang Lingkup Pembahasan Ilmu Falak}

Ilmu falak atau ilmu hisab pada garis besarnya ada dua macam, yaitu 'ilmi dan 'amali.'

Ilmu falak 'ilmi\} adalah ilmu yang membahas teori dan konsep benda-benda langit, misalnya dari segi asal mula kejadiannya (cosmogoni), bentuk dan tatahimpunannya (cosmologi), jumlah anggotanya (cosmografi), ukuran dan jaraknya (astrometrik), gerak dan gaya tariknya (astromekanik), dan kandungan unsur-unsurnya (astrofisika). Ilmu falak yang demikian ini disebut theoretical astronomy.

Sedangkan ilmu falak 'amali> adalah ilmu yang membahas perhitungan untuk mengetahui posisi dan kedudukan benda-benda langit antara satu dengan lainnya. Ilmu falak 'amali ini disebut practical astronomy. Ilmu falak 'amali inilah yang oleh masyarakat umum dikenal dengan ilmu falak atau ilmu hisab

1 P. Simamora, Ilmu Falak (Kosmografi), (Jakarta: CV. Pedjuang Bangsa, Cet. XXXII, 1987), 3.

2 Muhyiddin Khazin, Ilmu Falak dalam Teori dan Praktik (Yogyakarta: Buana Pustaka, 2004), 4. dalam pemahaman saat ini. Dan hanya bagian inilah saat ini yang dipelajari umat Islam, sebagai akibat dari pragmatisme pemikiran dan ortodoksi keilmuan. Sehingga ilmu falak yang dipelajari dalam Islam rata-rata hanya berkisar pada 4 hal: (1) arah kiblat ${ }^{3}$, (2) waktu-waktu shalat $^{4},(3)$ wal bulan ${ }^{5},(4)$ gerhana. $^{6}$

\section{Sejarah}

Di dalam al-Qur'an banyak kita temukan ayat-ayat yang memberi isyarat dan sekaligus motivasi agar ummat Islam mempelajari, menguasai dan mengembangkan ilmu Falak. Isyarat tersebut bisa diketahui antara lain melalui 3 hal berikut:

\footnotetext{
3 Ilmu falak yang membahas arah kiblat pada dasarnya adalah menghitung besaran sudut yang diapit oleh garis meridian yang melewati suatu tempat yang dihitung arah kiblatnya dengan lingkaran besar yang melewati tempat yang bersangkutan dan ka'bah, serta menghitung jam berapa matahari itu memotong jalur menuju ka'bah.

4 Sedangkan ilmu falak yang membahas waktu-waktu shalat pada dasarnya adalah menghitung tenggang waktu antara ketika matahari berada di titik kulminasi atas dengan waktu ketika matahari berkedudukan pada awal waktu-waktu shalat 5 Pembahasan awal bulan dalam ilmu falak adalah menghitung waktu terjadinya ijtima' (konjungsi), yakni posisi matahari dan bulan berada pada satu bujur astronomi, serta menghitung posisi bulan ketika matahari terbenam pada hari terjadinya konjungsi itu.

Sementara yang dibahas dalam gerhana adalah menghitung waktu terjadinya kontak antara matahari dan bulan, yakni kapan piringan bulan mulai menutupi piringan matahari dan lepas darinya pada gerhana matahari, serta kapan pula bulan mulai memasuki kereucut bayangan bumi dan tidak dikenai sinar matahari sehingga bulan menjadi gelap (gerhana bulan).
} 
1. Istilah-istilah astronomi yang digunakan oleh al-Qur'an, misalnya kata al-najm atau al-nujum (bintang-bintang), al-buruj (kumpulan bintang), al-ard (bumi), al-syams (matahari), dan al-qamar (bulan).

2. Ayat-ayat al-Qur'an yang menjelaskan keadaan, posisi dan gerak benda-benda langit, misalnya surat Yunus (10):5, yang menjelaskan bahwa Allah swt menetapkan manzilah (orbit) bagi perjalanan bulan supaya dapat diketahui bilangan waktu dan perhitungannya; al-Isra' (17):12, ${ }^{2} \quad$ yang

ا هُوْ آلذِى جَعَلَ آلشّمْسَ ضِيَّاءَ وَآلَقَمَرَ

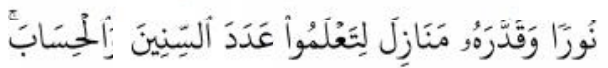

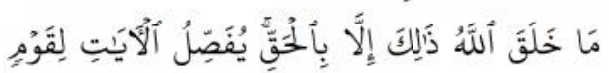

$$
\text { يَعْلَمُونَ }
$$

Artinya: Dia-lah yang menjadikan matahari bersinar dan bulan bercahaya dan ditetapkan-Nya manzilah-manzilah (tempattempat) bagi perjalanan bulan itu, supaya kamu mengetahui bilangan tahun dan perhitungan (waktu). Allah tidak menciptakan yang demikian itu melainkan dengan hak. Dia menjelaskan tanda-tanda (kebesaran-Nya) kepada orang-orang yang mengetahui.

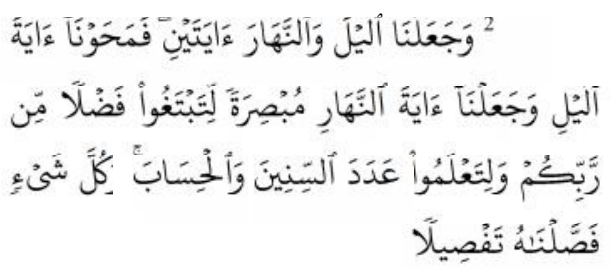

Artinya: Dan Kami jadikan malam dan siang sebagai dua tanda, lalu Kami hapuskan tanda malam dan Kami jadikan tanda siang itu terang, agar kamu mencari kurnia dari Tuhanmu, dan supaya kamu mengetahui bilangan tahun-tahun dan menjelaskan tentang manfaat diciptakannya bulan dan matahari; Yasin (36):37-40, ${ }^{3}$ yang menjelaskan tentang proses ijtima' sebagai bagian penting dari pergantian bulan baru; al-Rahman (55):5, 4 yang menjelaskan bahwa matahari dan bulan beredar menurut perhitungan.

3. Pemakaian istilah al-falak di dalam al-Qur'an yang berarti garis edar atau poros bendabenda langit. Ini berarti bahwa semua benda langit itu bergerak secara konstan pada garis edarnya.

perhitungan. dan segala sesuatu telah Kami terangkan dengan jelas.

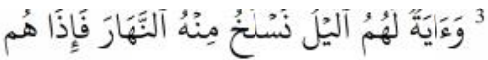

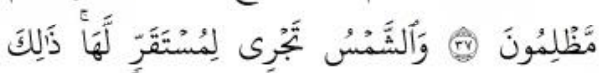

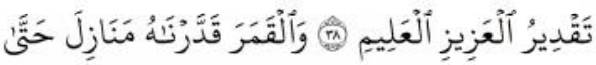

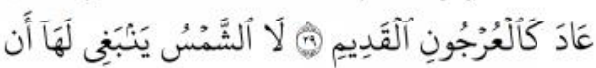

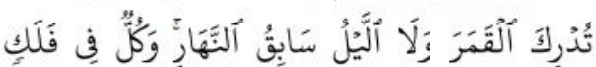

$$
\begin{aligned}
& \text { يَسْبَحُونَ }
\end{aligned}
$$

Artinya: dan suatu tanda (kekuasaan Allat yang besar) bagi mereka adalah malam; Kami tanggalkan siang dari malam itu, Maka dengan serta merta mereka berada dalam kegelapan. (37). Dan matahari berjalan ditempat peredarannya. Demikianlah ketetapan yang Maha Perkasa lagi Maha mengetahui.(38). Dan telah Kami tetapkan bagi bulan manzilah-manzilah, sehingga (setelah Dia sampai ke manzilah yang terakhir) Kembalilah Dia sebagai bertiok tandan yang tua (39). Tidaklah mungkin bagi matahari mendapatkan bulan dan malampun tidak dapat mendahului siang. dan masing-masing beredar pada garis edarnya. (40)

$$
4 \text { آلشَمْسُ وَآلَقَمَرُ بِكُسبَانٍ }
$$

Artinya: Matahari dan bulan (beredar) menurut perhitungan. 
Penegasan al-Qur'an itu kemudian dijabarkan oleh para ulama' ilmu Falak melalui penelitian-penelitian mereka, sehingga tidak heran bila banyak hasil penelitian mereka kemudian memberikan kontribusi bagi pengembangan ilmu astronomi modern. Beberapa pakar Muslim yang ikut mengembangkan ilmu Falak ini antara lain:

1. Abu Ja'far Muh \}ammad Ibn Musa al-Khawarizmi (780850 M). Ia memelopori penggunaan angka nol dalam ilmu hitung, yang metodenya kemudian dikenal sebagai algoritma. Karyanya yang populer adalah: Kitab alMukhtasar fi Hisab al-Jabr wa al-Muqabalah (Kompendium tentang Hitung Aljabar dan Persamaan). ${ }^{1}$ Karyanya ini banyak mempengaruhi pemikir Eropa dan diterjemahkan ke dalam bahasa Latin oleh Robert Chester pada tahun 1140 M/535H dengan judul Liber Algebras et Almucabola. ${ }^{2} \mathrm{Al}-$ Khawarizmi adalah orang pertama yang menggunakan konsep sinus, yang dengan konsep ini dia mempermudah perhitungan Ptolemeus yang menggunakan konsep busur.

2. Abu al-Wafa' al-Khurasani (940-998 M), seorang ahli

${ }^{1}$ Taufik Abdullah (ed), Ensiklopedi Tematis Dunia Islam: Pemikiran dan Peradaban, (Jakarta: PT. Ichtiar Baru Van Hoeve, Jilid 4, tt.), 238-9.

E. Van Donzel, Islamic Desk Reference, (Leiden: E. J. Brill, 1994), 213215 . astronomi dan matematika yang mengembangkan trigonometri. Dialah orang pertama yang mengemukakan teori sinus untuk segitiga bola. Dia pula yang mulamula menggunakan istilah tangen, cotangen, secan, cosecan dalam trigonometri serta membuktikan hubungan antara keenam fungsi trigonometri. ${ }^{3}$

3. Abu 'Abdullah al-Battani (858-929 M), seorang ahli astronomi dan geografi yang dikenal di Eropa sebagai Albategnus. Ia banyak menemukan rumus dasar trigonometri yang digunakan untuk penelitian di bidang astronomi. ${ }^{4}$

4. Abu Nasr Mansur Ibn 'Ali Ibn 'Iraq, seorang ahli astronomi dan matematika yang hidup sekitar tahun 1000 M. Ada sekitar lima belas buku matematika dan astronomi yang ditulisnya Di antaranya adalah Jadwal alDaqaiq (Tabel Fungsi Trigonometri). ${ }^{5}$

5. Abu Rayhan al-Biruni (9731048 M). Beliau murid Abu Nasr Mansur Ibn 'Ali Ibn 'Iraq yang hidup satu zaman dengan Ibn Sina. Di samping ahli geografi dan astronomi, beliau juga dikenal sebagai

3 Mehdi Nakosteen, History of Islamic Origins of Western Education A.D. 800 - 1350; with an Intruduction to Medieval Muslim Education, terj. Joko S. Kahhar dan Supriyanto Abdullah (Surabaya: Risalah Gusti, 2003), 233.

4 Taufik Abdullah (ed), Ensiklopedi ..., 239.

5 Ibid. 
tokoh pengembang ilmu Falak, yang membuat tabeltabel sinus dan tangen yang pertama dalam sejarah matematika. ${ }^{1} \quad$ Karya monumentalnya adalah: "AlQanun al-Mas'udi" (sebuah ensiklopedi astronomi yang di-persembahkan kepada sultan Mas'ud Mahmudi) yang ditulis pada tahun $421 \mathrm{H}$ (1030 M). Al-Biruni adalah orang yang pertama menolak teori geosentrisnya Ptolemeus dan menganggap teori geosentris itu tidak masuk akal. $^{2}$

6. Nasiruddin al-Tusi (1201$1274 \mathrm{M}$ ), yang telah meneliti tentang lintasan, ukuran dan jarak planet Merkurius. Ia juga meneliti tentang "terbit dan tenggelam", "bidang gerak", "ukuran dan jarak matahari dan bulan". Semua hasil penelitiannya itu bisa dibaca dalam kitab: $a l$ Mutawassit bain alHandasah wa al-Hai'ah (kumpulan karya terjemah tentang geometri dan astronomi); al-Tazkirat fi 'Ilm al-Hay'ah (sebuah karya hasil penelitian di bidang astronomi yang mendapat banyak ulasan para astronom Timur dan Barat); dan kitab Zubdat al-Hay-ah (intisari astronomi). ${ }^{3}$

\footnotetext{
${ }^{1}$ Ibid.

2 Ahmad Baiquni, Al-Qur'an, Ilmu Pengetahuan dan Teknologi, (Yogyakarta: Dana Bhakti Prima Yasa, Cet. IV, 1996), 9.

3 'Abdul 'Aziz Dahlan (ed), Ensiklopedi ..., 306
}

7. Al-Farghani, seorang astronom Muslim yang berasal dari Farghana (Uzbekistan). Diantara karyanya adalah: Jawami' Ilm al-Nujum wa al-H\{arakat al-Samawiyyah, Usul al-'Ilm al-Nujum, Al-Madkhal Ila 'Ilm al-Hay'at al-Falaky, Kitab al-Fusul al-Thalasin. Semua karya beliau itu sudah diterjemahkan ke dalam bahasa Latin Spanyol oleh John Hispalensis dari Seville dan Gerard dari Cremona pada tahun $1493 .^{4}$

8. Abu Ma'shar al-Falaki , dengan karyanya : Isbat al'Ulum dan Hay'at al-Falaky.

9. Muhammad Turghay Ulughbek (1394-1449 M). Beliau seorang astronom yang membangun observatorium di Samarkand pada tahun $1420 \mathrm{M}^{6}$

\section{Kondisi Saat Ini}

Berbicara tentang kondisi ilmu falak saat ini, mungkin sama dengan kondisi ilmu-ilmu yang lain di dunia Islam, yakni masa kejumudan yang sudah berlangsung sejak sekitar 6 abad yang lalu. Hal ini misalnya bisa kita lihat dari jumlah pakar (yang berpendidikan S3) dari tiap satu juta penduduk, sebagaimana

${ }^{4}$ E. J. Brill's, First Encyclopaedia of Islam 1913-1936 (Leiden: E.J. Brill, vol. III, 1993), 67.

5 A. Hasjmy, Sejarah Kebudayaan Islam (Jakarta: Bulan Bintang, Cet. V, 1995), 297.

6 John L. Esposito, The Oxford Encyclopaedia of The Modern Islamic World, (New York: Oxford University Press, vol. I, Cet. I, 1995), 147 dan 271. 
tergambarkan dalam diagram statistic berikut:

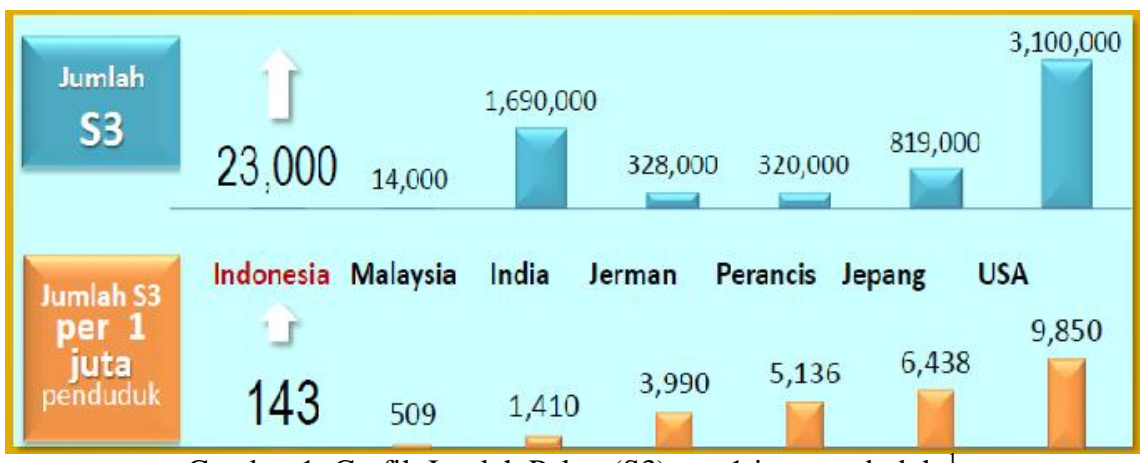

Gambar 1: Grafik Jumlah Pakar (S3) per-1 juta penduduk ${ }^{1}$

1 Agung Sudaryono, Latar Belakang dan Profil Lembaga Pengelola Dama Pendidikan (Jakarta: Direktorat Perencanaan Usaha dan Pengembangan Dana Kementerian Keuangan, 2014), 10. 
Indonesia sebagai representasi Negara dengan jumlah penduduk muslimnya terbesar di dunia, hanya memiliki 23.000 doktor dengan rasio 143 orang doctor dari setiap satu juta penduduk. Perbedaan yang sangat jauh sekali dibandingkan dengan Negara-negara maju yang mayoritas penduduknya non-muslim. Lebih jauh lagi kalau kita lihat dari sisi guru besarnya, saat ini Indonesia baru memiliki 5097 orang guru besar. ${ }^{1}$ Dan dari 5097 guru besar di Indonesia baru ada 1 guru besar astronomi yaitu Prof. Dr. Thomas Djamaluddin (Saat ini menjabat Kepala Lembaga Penerbangan dan Antariksa Nasional).

\section{Arah Pengembangan}

Tidak bisa dipungkiri, bahwa setelah mengalami masa keemasan selama kurang lebih 500 tahun secara berturut-turut umat Islam mulai disisihkan di bidang ilmu pengetahuan alam atau kauniyah oleh bangsa Eropa, kemudian Amerika, dan selanjutnya banga Jepang. Dan kini menempati posisi paling lemah. $^{2}$

Sebagai akibatnya, umat Islam lemah dalam bidang teknologi, karena teknologi modern bertumpu pada pada ilmu kauniyah. Teknologi merupakan penerapan ilmu kauniyah untuk dapat memanfaatkan alam bagi kesejahteraan umat. Kita dijajah, dikuasai, diperintah serta dieksploitir selama berabad-abad oleh Negara barat karena tidak mampu

http://print.kompas.com/baca/2015/10/29/Ju mlah-Guru-Besar-di-Indonesia-MasihMinim (29 Oktober 2015).

2 Baiquni, al-Qur'an, 148. menandingi kemampuan teknologi dan persenjataan mereka.

Untuk itu kewajiban kita adalah menguasai dan mengembangkan ilmu seperti sediakala, sebab ini merupakan perintah syari'at. Untuk menginsafi betapa pentingnya ilmu kauniyah yang merupakan dasar bagi teknologi itu, Allah sudah mengingatkan dalam surat al-Ja>thiyah ayat 13:

Artinya: Dan Dia telah menundukkan untukmu apa yang di langit dan apa yang di bumi semuanya, (sebagai rahmat) daripada-Nya. Sesungguhnya pada yang demikian itu benar-benar terdapat tanda-tanda (kekuasaan Allah) bagi kaum yang berfikir.

Sebagai makhluk yang ditetapkan oleh Allah sebagai pengelola alam, manusia dikaruniai kemampuan untuk dapat memanfaatkan alam sekitarnya dengan cara-cara tertentu yang disebut teknologi, yaitu dengan mempergunakan hokum-hukum alam atau tegasnya peraturan yang telah digariskan oleh Allah untuk diikuti seluruh alam.kauniyah yang telah disusun dan dikuasai sebagai akibat dari penelitian terhadap sifat dan kelakuan alam itu sendiri dengan menggunakan akal dan fikiran seperti yang diperintahkan oleh 
Allah dalam surat Yunus ayat 101, dan surat al-Ghathiyah ayat $17-21{ }^{2}$

Selanjutnya yang paling penting adalah kita segera bangkit untuk melangkah dan berbuat lebih baik dari apa yang sudah dicapai hari ini. Namun bukan asal berbuat dengan tidak ada perencanaan. Untuk itu mengacu kepada kondisi keilmuan umat Islam saat ini, khususnya dalam bidang ilmu falak, arah pengembangan yang harus dilakukan antara lain:

\section{a. Kurikulum}

Sudah terlalu lama ilmu falak ini mengalami dikotomi, sehingga yang dipelajari saat ini hanya yang terkait dengan urusan pelaksanaan ibadah dengan mengabaikan yang lain. Padahal ilmu falak praktis tersebut hanya merupakan bagian kecil dari ilmu falak dalam konsepsi

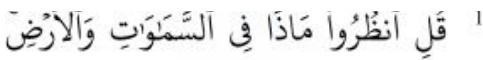

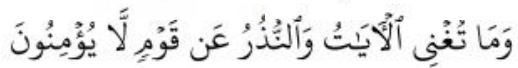

Artinya: Katakanlah: "Perhatikartialt apa yaag ada di langit dan di bumi. tidaklah bermanfaat tanda kekuasaan Allah dan Rasul-rasul yang memberi peringatan bagi orang-orang yang tidak beriman".

$$
\begin{aligned}
& 22
\end{aligned}
$$

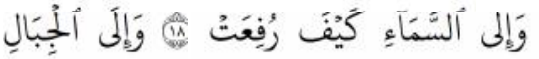

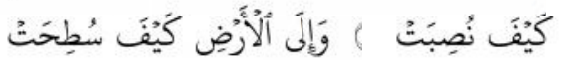

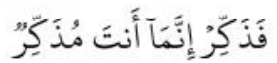

Artinya: 17. Maka Apakah mereka tialak memperhatikan unta bagaimana Dia diciptakan, 18. dan langit, bagaimana ia ditinggikan? 19. dan gunung-gunung bagaimana ia ditegakkan? 20. dan bumi bagaimana ia dihamparkan? 21. Maka berilah peringatan, karena Sesungguhnya kamu hanyalah orang yang memberi peringatan. yang sesungguhnya. Kurikulum ilmu falak harus dikembalikan kepada hakekat ilmu falak yang sesungguhnya, dengan tidak mendikotomikan antara yang terkait dengan urusan ibadah dan nonibadah. Semangat integrasi keilmuan yang diusung oleh UIN-UIN di Indonesia juga harus dimanfaatkan sebagai sarana mengembalikan kurikulum ilmu falak kepada konsepsi yang sesungguhnya. Syariah tidak pernah mendikotomikan sebah ilmu, manusialah yang mendikotomikannya yang didasarkan pada pragmatism pemikiran serta ortodoksi kelompok. Tidak ada satu syariat-pun yang berisi pembatasan serta dikotomi ilmu. Bahkan Nabipun memerintahkan untuk mencari ilmu meskipun di negeri China.

Sasaran pendidikan kita harus mengarah kepada pembentukan pribadi yang utuh, dimana tiap individu diajarkan untuk beribadah sebagai umat Islam dan mengetahui hal-hal yang esensial dalam agama serta dididik untuk berakhlak sebagai muslim yang baik, juga bisa mengembangkan ilmu kauniyah dengan metodologinya untuk diterapkan di berbagai bidang.

$$
\text { Maka sudah sudah }
$$
selayaknyalah UIN memilki fakultas sains, sebagai sarana mengembangkan ilmu usul dan ilmu kauniyah dalam satu universitas untuk mempercepat integrasi keilmuan dan segera menghilangkan dikotomi.

\section{b. Sarana dan Teknologi}

Sarana dan teknologi adalah hal tidak kalah pentingnya dengan kurikulum. Sebaik apapun 
kurikulum, tanpa didukung sarana dan teknologi tidak akan bisa mencapai hasil maksimal. Saat ini kita (khususnya orang Indonesia) terlalu disibukkan dengan perdebatan yang tidak jelas arahnya. Ilmu Falak adalah ilmu kauniyah yang pondasi utamanya adalah penelitian alam. Oleh karena itu sarana dan teknologi untuk mendukung penelitian mutlak diperlukan. Dalam kaitannya dengan ilmu falak atau astronomi ini keberadaan observatorium adalah sesuatu yang mutlak.

Sebagai ilustrasi, saat ini di Indonesia baru ada kurang lebih 8 buah observatorium dengan perincian sebagai berikut: ${ }^{1}$ penulis.

\footnotetext{
${ }^{1}$ Data dari hasil penelusuran
} 


\begin{tabular}{|c|c|c|c|}
\hline No & Nama & Owner & Alamat \\
\hline 1 & $\begin{array}{l}\text { Bosscha } \\
\text { Observatory }\end{array}$ & $\begin{array}{l}\text { Pemerintah/Institut } \\
\text { Teknologi } \\
\text { Bandung }\end{array}$ & $\begin{array}{l}\text { Jl. Peneropong Bintang, } \\
\text { Lembang, Kabupaten } \\
\text { Bandung Barat, Jawa } \\
\text { Barat (022) 2786027 }\end{array}$ \\
\hline 2 & $\begin{array}{l}\text { Planetarium dan } \\
\text { Observatorium } \\
\text { Jakarta }\end{array}$ & Pemda DKI Jakarta & $\begin{array}{l}\text { Taman Ismail Marzuki, Jl. } \\
\text { Cikini Raya No. } 73 \text {, } \\
\text { Daerah Khusus Ibukota } \\
\text { Jakarta (021) } 2305146\end{array}$ \\
\hline 3 & $\begin{array}{l}\text { Assalaam } \\
\text { Observatory }\end{array}$ & $\begin{array}{l}\text { Pondok Pesantren } \\
\text { Assalaam } \\
\text { Kartasura }\end{array}$ & $\begin{array}{l}\text { Komplek PPMI Assalaam } \\
\text { No.3 Kecamatan } \\
\text { Kartasura, Kabupten } \\
\text { Sukoharjo, Jl. Garuda } \\
\text { Mas, Pabelan, Kota } \\
\text { Surakarta, Jawa Tengah } \\
\text { (0271) } 718741 \text { ext. } 226\end{array}$ \\
\hline 4 & $\begin{array}{l}\text { Watoe Dhakon } \\
\text { Observatory }\end{array}$ & STAIN Ponorogo & $\begin{array}{l}\text { Jl. Pramuka No. } 156 \\
\text { Ponorogo (0352) } 481277\end{array}$ \\
\hline 5 & $\begin{array}{l}\text { Observatorium } \\
\text { Ilmu Falak }\end{array}$ & $\begin{array}{l}\text { UNMUH Sumatera } \\
\text { Utara }\end{array}$ & $\begin{array}{l}\text { J1. Denai No } 217 \text { Lt. } 7 \text { Gd } \\
\text { Pascasarjana UMSU, } \\
\text { Sumatera Utara } \\
\text { Telepon: 0853-5803-3907 }\end{array}$ \\
\hline 6 & $\begin{array}{l}\text { Observatorium } \\
\text { Tgk. Chiek Kuta } \\
\text { Karang Lhoknga }\end{array}$ & $\begin{array}{l}\text { Kanwil } \\
\text { Kementerian } \\
\text { Agama Prov. Aceh }\end{array}$ & $\begin{array}{l}\text { Mon Ikeun, Kec. } \\
\text { Lhoknga, Kabupaten Aceh } \\
\text { Besar, Aceh }\end{array}$ \\
\hline 7 & $\begin{array}{l}\text { Imah Noong } \\
\text { Observatory }\end{array}$ & $\begin{array}{l}\text { Hendro Setiyanto, } \\
\text { Lembang, Bandung }\end{array}$ & $\begin{array}{l}\text { Jalan Pasar Laksana } \\
\text { No.31, RW 12, RT 02,, } \\
\text { Wangunsari, Lembang, } \\
\text { Kabupaten Bandung } \\
\text { Barat, Jawa Barat (022) } \\
\text { 2788508 }\end{array}$ \\
\hline 8 & $\begin{array}{l}\text { Al-Buruj } \\
\text { Observatory }\end{array}$ & $\begin{array}{l}\text { Joko Prasetiyo, } \\
\text { Kudus }\end{array}$ & $\begin{array}{l}-6.794694^{\circ} \mathrm{LS} \\
110.860160^{\circ} \mathrm{BT} \\
\text { Kudus, Indonesia } 59324\end{array}$ \\
\hline
\end{tabular}


Dari data tersebut, bisa digambarkan seberapa besar perhatian pemerintah Indonesia yang berpenduduk muslim terbesar di dunia terhadap pentingnya ilmu falak. Artinya, pemerintah sama sekali belum mempunyai arah kebijakan terhadap kemajuan ilmu falak/astronomi di Indonesia. Justru inisiatif baru datang dari individuindividu yang sebagian bekerja pada sebuah instansi.

Bila dibandingkan dengan Negaranegara maju, misalnya USA memilki ratusan observatorium berskala nasional, Jepang ada 16 observaorium nasional, India 17 observaorium nasional. ${ }^{39}$ Belum lagi observatorium milik lembaga pendidikan dan milik perseorangan yang jumlahnya tidak terhingga. Tentu dengan tingkat teknologi yang jauh dari yang dimilki oleh Indonesia.

Idealnya, Indonesia dengan luas wilayah yang sedemikian, minimal memilki observatorium berskala nasional pada masing-masing wilayah propinsi, sebagai sarana penelitian dan pengembangan sumber daya manusia untuk menghilangkan ortodoksi keilmuan yang selama ini membelenggu nalar dan daya pikir umat ini.

Penulis meyakini dikotomi dan ortodoksi keilmuan falak antara lain disebabkan kurangnya wawasan umat dalam melihat dan memahami ayat-ayat kauniyah yang disebabkan tidak adanya sarana bagi umat ini untuk berbuat lebih banyak. Dengan peningkatan wawasan terhadap ayat-ayat kauniyah penulis meyakini ortodoksi pengikut hisab dan ru'yat akan hilang dengan sendirinya.

\section{Kesimpulan}

Sudah terlalu lama umat Islam terjebak dalam kejumudan berfikir, khususnya dalam bidang Ilmu Falak.

https://en.wikipedia.org/wiki/List_of_astronomical_o bservatories (10 Januari 2015).
Reduksi dan pembatasan wilayah kajian dari disiplin ilmu ini justru mengakibatkan kemunduran berfikir umat. Momentum peralihan status berbagai perguruan tinggi menjadi Universtas (Khususnya Universitas Islam Negeri/UIN) yang mengusung semangat Unity of Science seharusnya kita gunakan sebagai pijakan dalam berbenah untuk mengembalikan disiplin ilmu ini pada khittahnya. Pembenahan bisa dimulai dari sisi kurikulum maupun berbagai peralatan pendukung baik berupa laboratorium maupun observatorium yang merupakan sumber data dari ilmu ini.[]

\section{Daftar Pustaka}

Abdul 'Aziz Dahlan (ed.), Ensiklopedi Hukum Islam, (Jakarta: PT. Ichtiar Baru Van Hoeve, Cet. I, Jilid I, 1997).

Agung Sudaryono, Latar Belakang dan Profil Lembaga Pengelola Dama Pendidikan (Jakarta: Direktorat Perencanaan Usaha dan Pengembangan Dana Kementerian Keuangan, 2014).

Ahmad Baiquni, Al-Qur'an, Ilmu Pengetahuan dan Teknologi, (Yogyakarta: Dana Bhakti Prima Yasa, Cet. IV, 1996).

A. Hasjmy, Sejarah Kebudayaan Islam, (Jakarta: Bulan Bintang, Cet. V, 1995).

A.W. Munawwir, Kamus Al-Munawwir Arab-Indonesia Terlengkap, (Surabaya: Pustaka Progressif, Edisi Kedua, Cet. XIV, 1997).

A. Yusuf Ali, The Holy Qur'an Text Translation and Commentary, (USA: Amana Corp, 1934).

Departemen Pendidikan dan Kebudayaan, Kamus Besar Bahasa Indonesia, (Jakarta: Balai Pustaka, Edisi Kedua, Cet. IX, 1999). 
E. J. Brill's, First Encyclopaedia of Islam 1913-1936, (Leiden: E.J. Brill, vol. III, 1993).

E. Van Donzel, Islamic Desk Reference, (Leiden: E. J. Brill, 1994).

Hafidz Dasuki, Ensiklopedi Islam, (Jakarta: : PT. Ichtiar Baru Van Hoeve, Cet. I, Jilid I, 1994).

John L. Esposito, The Oxford Encyclopaedia of The Modern Islamic World, (New York: Oxford University Press, vol. I, Cet. I, 1995).

John M. Echols dan Hassan Shadily, Kamus Inggris Indonesia, (Jakarta: PT. Gramedia, 1983).

Mehdi Nakosteen, History of Islamic Origins of Western Education A.D. 800 - 1350; with an Intruduction to Medieval Muslim Education, terj. Joko S. Kahhar dan Supriyanto Abdullah (Surabaya: Risalah Gusti, 2003).

Muhyiddin Khazin, Ilmu Falak dalam Teori dan Praktik (Yogyakarta: Buana Pustaka, 2004).

P. Simamora, Ilmu Falak (Kosmografi), (Jakarta: CV. Pedjuang Bangsa, Cet. XXXII, 1987).

Taufik Abdullah (ed), Ensiklopedi Tematis Dunia Islam: Pemikiran dan Peradaban, (Jakarta: PT. Ichtiar Baru Van Hoeve, Jilid 4, tt.).

https://id.wikipedia.org/wiki/NASA (diakses 10 Januari 2016).

http://print.kompas.com/baca/2015/10/29/Ju mlah-Guru-Besar-di-IndonesiaMasih-Minim (29 Oktober 2015).

https://en.wikipedia.org/wiki/List_of_astron omical_observatories (10 Januari 2015). 